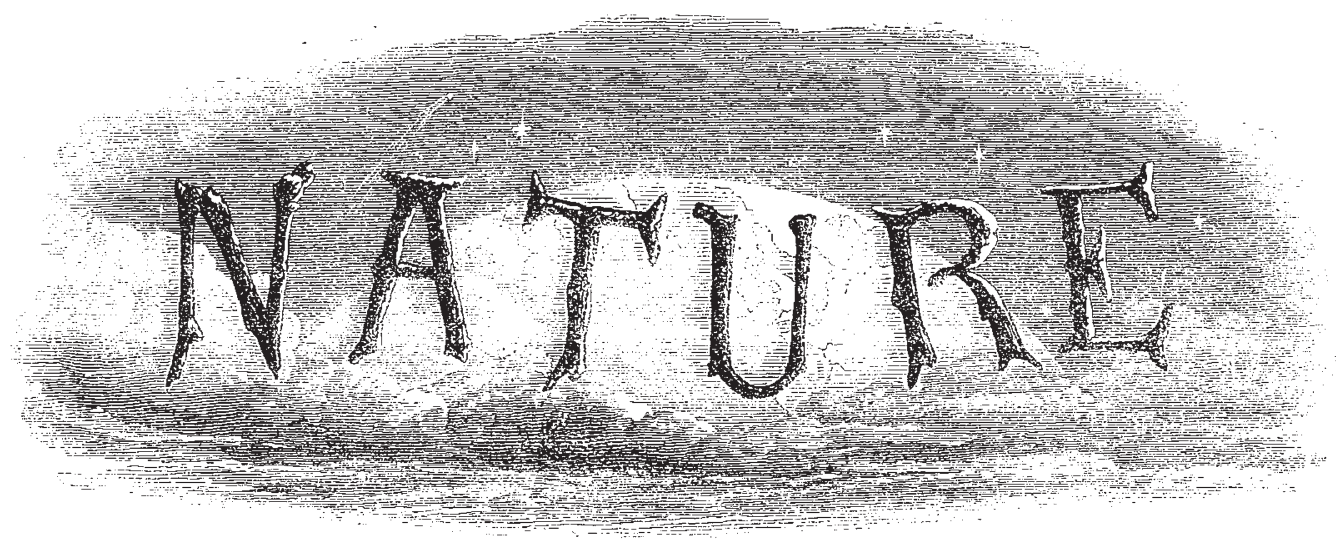

A WEEKLY ILLUSTRATED JOURNAL OF SCIENCE

"To the solid ground

of Nature trusts the mind which builds for aye."-Wordswortin

THURSDAY，NOVEMBER 2, 1876

\section{THE ARCTIC EXPEDITION}

1 is pleasing to be able to begin our fifteenth volume with congratulations to the officers and men of a 13ritish Arctic Expedition on their safe return. On another page we give a summary of the results obtained so far as these can yet be known. It will be seen that substantial additions have been made to our knowledge in many directions, and that the expedition must be pronounced a success. True, the Pole has not been reached, but this, in the consideration of all but the mere lovers of sensation, is a smail matter; our explorers hive done the next best thing to reaching it, they have proved that the Pole was impracticable this year from the quarter whence success was most to be expected. It is evident from the few hints which have already been pullished, that when all the tale is told, it will be quite as thrilling, and full of dangers and bravery, as any previous narrative of Arctic exploration. So far as the conduct of the expedition is concerned, it seems to have been all that could be wished; the original programme was, on the whole, closely stuck to, and the desperately hard and dangerous work was done in the most systematic and economical way at present possible. Everybody seems to have behaved admirably ; there seems to have been no fault whatever to find with anyone; and so much has Capt. Nares endeared himself to officers and men, that he earned for bimself the common title of "the father" of the expedition.

It was hardly to be expected that an expedition, on such an errand, and with such unprecedented dangers to face as this one has had, would return without casualties; they have left four of their comrades behind them. Of these one only died as the result of frost bite, the three others succumbing to that most dreaded of all Arctic foes, scurvy. No similar expedition ever left any country so well provided with everything that could be thought of conducive to sustenance and protection. There was an ample supply of fresh provisions of all kinds, sufficient medical staff, and all precautions were evidently taken

VoL. XV.-No. 366 throughout the long winter to keep everyone employed, and cheerful, and duly exercised. Yet, in all the sledgeparties, scurvy broke out with a virulence and to an extent not experienced, we believe, in any recent Arctic expedition. The cause of this outbreak will no doubt give much food for thought for some time to come, some thinking that the unusual length and intensity of the darkness may have had something to do with it. The darkness seems to have been much more intense, and certainly was longer-continued than ever before experienced, and such a condition, not to mention its effect on the spirits of the men, must necessarily, one would think, exercise some deleterious physical influence on the body. This is a point deserving of careful consideration; meantime we cannot but admiie the way in which officers and men of these sledge-purties did their work in spite of physical weakness and terrible suffering; it would, however, have been surprising had the record been otherwise.

No men could have exerted themselves morc to accomplish the popular, but really minor, object of their expedition, and none could have been more honourably bafiled. The ice was met with off Cape Sabine in $7 S^{\circ} 4 \mathrm{I}^{\prime} \mathrm{N}$., and from that time till the Alert was compelled to take up her quarters in $82^{\circ} 27^{\prime}$, it was a constant battle with ice of a thickness never before met with. The ice was from 100 to 150 and even 200 feet thick, resembling more a pell-mell assemblage of icebergs than the usual floes; to have been nipped between the masses of such ice would certainly have been fatal. Commander Markham in his daring attempt to carry out the instructions of the expedition by penetrating as far to the north as possible, found the ice piled in such rough and hilly hummocks that progress was only possible at the rate of a mile a day, and he wisely returned after reaching $83^{\circ} 20^{\prime} \mathrm{N}$., the highest autheritic latitude yet attained.

Capt. Parry's long and weary journey, which reminds one to a certain extent of that of Commander Markham, was only as far as $82^{\circ} 45^{\prime}$; the Austro-Hungarian expedition of I $872-4$ reached $82^{\circ} 5^{\prime}$, though they saw as far as $83^{\circ}$; while Hall with the Polaris sailed without let or hindrance in 1872 over the same ground as the Alert and Discovery for 700 miles to $82^{\circ} 16^{\prime} \mathrm{N}$. in the short space of one week. 
Any such frightful ice-barrier as that reported, and, let us add, admirably photographed, by our expedition was not seen by Hall and his men; and indeed it has been stated that had it not been for the scruples of the second in command, Buddington, Hall would have pushed still further northwards, all on board, except Buddington, who had no heart in the work, agreeing that the undertaking was perfectly practicable. Meyer, in his evidence before the U.S. Commission, declared that if $82^{\circ} 16^{\prime}$ could have been passed, there was nothing to hinder a ship reaching $85^{\circ}$ or $86^{\circ}$ " or even farther. Had poor Hall not met with an untimely death, the attempt would certainly have been made in the following summer. This terrible ice-barrier, then, before which our expedition has wisely returned, does not appear to be a constant phenomenon so far south, for Hall's observations have been generally accepted as perfectly trustworthy. May there not have been some cause at work in the high north to push the thick-ribbed ice south to the northern entrance of Robeson Channel? This seems to have been an unusually severe season in the north ; icebergs were met with in abundance a week or two ago far south in the Atlantic, and last week we reported the wreck of a whole fleet of whalers in the Behring Straits region. If the latter casualty has been produced by ice, it would seem to show that some cause has been at work this season to render it unusually unfavourable for Arctic work. It is perhaps worth noting here, at least, that $187 \mathrm{r}$ was a maximum, while 1876 is a minimum, sun-spot year. The temperature was undoubtedly the coldest on record, neither the Polaris nor the Austro-Hungarian expedition experiencing anything like it, namely, $104^{\circ}$ of frost. There was no stint of animal life in the region in which the Polaris wintered, and as far north as the expedition penetrated, it was observed, while the Austro-Hungarian expedition found the cliffs swarming with life at their farthest north point. The dearth of animal life is a noticeable feature in the restilts of our expedition; it ceased altogether at a short distance to the north of the Alert's quarters. The prevailing wind during the sojourn of the Polaris was from the north-east ; this year it is stated scarcely any easterly wind was noticed, but a strong current and drift set constantly in from the west along the north coast of America. We mention these points simply to suggest that the conditions met with by our gallant expedition can hardly without further observations be regarded as the normal ones. Round the Pole doubtless there must be a permanent barrier of impenetrable floe-bergs, for it would be ridiculous to suppose that I50 feet thick ice of thousands of square miles in extent is melted and re-formed every year. But is it possible that usually this barrier lies further north than our expedition found it?

As to positive discoveries, an unprecedentedly rich collection of observations in all departments have been obtained. It will be seen from our map that positive additions have been made to Arctic geography. With the exception of Hayes Inlet, all the coast from Cape Farewell to the northern end of Robeson Channel is now laid down, and considerable advances have been made west along the American, and east along the North Greenland coast, in the former case to $86^{\circ} 30^{\prime} \mathrm{W}$., and in the latter to $48^{\circ} 33^{\prime} \mathrm{W}$. President Land does not exist, no land having been seen north of Cape Columbia in $83^{\circ} 7^{\prime} \mathrm{N}$. It was a pity that Peter- mann Fjord was blocked up with ice, otherwise it might have been ascertained whether or not it divides Greenland in two, as has been conjectured. There is little doubt, at any rate, that Greenland is an island, and that it does not extend right across to Wrangell Land as Petermann conjectured. For the more important scientific observations we must wait some little time, but we have reason to believe they are abundant and of the highest value. The diift of the current along the North American coast it will be seen, is from the west, and it is possible it may come right across from Behring Straits. A magnificen series of tidal observations has been obtained, entirely confrmatcry of the conclusions that Bessels came to, viz., that the tides in the north of Smith's Sound come from the Pacific. It would be interesting now to know what lies between Parry Islands and tha $n \circ$ wly discovered coast, and whether currents have an unobstructed passage from Behring Straits acruss the Polar Sea. The magnetic observations entirely endorse the theory on which the charts have been constructed; and had it not been for a change of officers and an accident to the clock, the pendulum observations for determining the figure of the earth would have been completed and of the greatest interest. Capt. Feilden, the naturalist, whose exertions are beyond all praise, obtained admirable results in his department.

We may be permitted to say that we think Capt. Nares has acted gracefully and generously in his selection of names for the lands discovered ; the most northern point discovered now bears the name of Cape Colmmbia. It was in keeping with this disposition to recognise America's claims to remembrance that Capt. Nares paid a deserved tribute to the brave Hall by affixing to his no longer lonely grave a brass tablet containing a suitable inscription.

Altogether we have every reason to be satisfied with the conduct and results of the expedition, and thankful that these results have Deen obtained with so little loss. It might have been otherwise, for the Discovery was within a minute of being crushed by an iceberg, and had it not been for an accident to the Alert's screw, she would certainly have pushed further north and got into a position from which it would have been impossible to extricate her. Many lessons with regard to future Arctic work are to be learned from the experiences of this latest expedition. We would also remind our readers of the plan advocated by Weyprecht, and recommended by a German Government Commission, to establish at suitable points all round the Polar region a series of permanent stations from which the Arctic citadel can be slowly but surely sapped. The recommendations of the German Government Commission we consider so important, that although we published them at the time, we think it appropriate to reproduce them here in the present connection, and the admirable scientific spirit in which the subject is approached is worthy of note.

"I. The exploration of the Arctic regions is of great importance for all branches of science. The Commission recommends for such exploration the establishment of fixed observing stations. From the principal station, and supported by it, are to be made exploring expeditions by sea and by land.

"2. The Commission is of opinion that the region 
which should be explored by organised German Arctic explorers, is the great inlet to the higher Arctic regions situated between the eastern shore of Greenland and the western shore of Spitzbergen.

"Considering the results of the second German Arctic expedition, a principal station should be established on the eastern shore of Greenland, and, at least, two secondary stations, fitted out for permanent investigation of different scientific questions, at Jan Mayen and on the western shore of Spitzbergen. For certain scientific researches the principal station should establish temporary stations.

"3. It appears very desirable, and, so far as scientific preparations are concerned, possible, to commence these Arctic explorations in the year 1877 .

"4. The Commission is convinced that an exploration of the Arctic regions, based on such principles, will furnish valuable results, even if limited to the region between Greenland and Spitzbergen; but it is also of opinion than an exhaustive solution of the problems to be solved can only be expected when the exploration is extended over the whole Arctic zone, and when other countries take their share in the undertaking.

"The Commission recommends, therefore, that the principles adopted for the German undertaking should be communicated to the Governments of the States which take interest in Arctic inquiry, in order to establish, if possible, a complete circle of observing stations in the Arctic zones."

But to come to any final decision on the subject at present, as have some of the daily papers, is premature, more especially as we have only mere hints of the work of the latest expedition before as. It is evident, however, that three courses are open to us: we may rest on our oars and comfort ourselves with the belief that no more can be done; we may make another dash, blind to a certain extent it must be with our present knowledge ; or, accepting the recommendation of the German Commission, a united and continuous sap may be commenced. But in order to come to a wise decision, men of science must long ponder over the enormous mass of new facts collected by the expedition, and not until this has been done can any opinion worth the stating be possibly arrived at.

Herc we would have ended had it not been for the lamentable tone assumed by our leading newspaper in an article on the expedition in Tuesday's issue. It will be remembered that from the first, for some unaccountable reason, the Times set its face against the expedition, and prophesied that no good could come of it; now it utters a lonely shout of triumph at the supposed success of its prophecy. For the Times appears to be so ill-informed 2.5 to believe that the main, if not the sole, object of the expedition was to reach the Pole ; if it failed in doing this, then, in the eyes of the Times, it was a complete failure. But this is sheer ignorance, real or assumed, on the part of the Times; for no informed person ever dreant that the only object of the well-equipped expedition was to gratify unintelligent curiosity and craving after sensation. The printed instructions of the expedition were essentially: "Reach the Pole if you can, but at any rate, in the light of the latest scientific knowledge, make all possible observations on the multifarious phenomena which can be seen to advantage alone in the Arctic regions." These instructions have been faithfully carried out and with complete success. Every effort was made to reach the Pole, and when the results are published it will be seen that no expedition ever brought home a richer harvest. Whether these results are worth the suffering and the sacrifice of life which the expedition experienced, is a question which will be answered in accordance with one's idea of what is worth running the risk of life for. In spite of the scream of the Times, and although no new market has been opened, the people of this country will simply feel proud, and be ennobled by the thought, that the latest deed of heroism has been done by Englishmen-that "the ancient spirit is not dead."

The nation desired the expedition, scientific bodies and scientific men counselled it and worked for it, Government, only after long consideration, willing and liberally granted funds; and out of the volunteers, officers and men, who, well knowing all the risks that would be run, eagerly offered themselves for the service, a dozen similar expeditions could have been equipped. Under these circumstances the Times' article is simply an impertinence.

\section{SCHIMPER'S "MOSSES OF EUROPE"}

Synopsis Muscorum Europaorum. Auctore W. P. Schimper. Vol. I.-Introductio, pp. 130. Vo\}. II.Specierum descriptio, pp. 886. Edit. 2. Stuttgartiæ, 1876. (London: Williams and Norgate.)

THIS long expected work has at last made its appearance, and all students of bryology will be grateful to possess such a vast storehouse of carefully arranged descriptive matter to help them in the determination of species ; no easy task at any time, and sometimes one of dificulty and trouble even to an expert.

The first edition appeared in 1860 , and we must frankly admit that we experienced some feelings of disappointment, on finding that almost the entire nomenclature and arrangement are identical with those of that edition; nay, in some respects we must look upon the classification as retrograde, for while in his classical work on the Spbagnaceæ, Prof. Schimper strongly insists on the elevation of this family to the rank of a class equivalent to those of Mosses and Hepatica, we here find him placing them along with Andrece and Archidium, as an appendage to the mosses, under the title of BRYINA ANOMALÆ; surely a most unphilosophical mode of dealing with them, since the three genera have nothing else in common but the large saccate calyptra, which had already led Hampe to separate them as a section-Saccomitria.

The Cleistocarpous order heads the series, though the author half apologises for still retaining it "as being convenient for beginners, and because the position of some of them among the Stegocarpi is uncertain." Several of our best bryologists, however, have long felt that the solitary character of possessing a capsule without a separable lid, is not sufficient to outweigh all other points of structure and habit, especially when it also necessitates keeping up two parallel series of forms in widely separated families, e.g., Pliascacece and Pottiacece. We would venture to differ from our author, and consider that Archidium is a near ally of Pleuridium, and that the absence of a columella is not so momentous a character as to require the separation of these genera to the extreme ends of the system ; while Andreaa as to its vegetative organs is essentially Grimmiaceous, but in its fruit standing apart 